\title{
Pneumologia
}

\section{TB endemic evolution in Romania in the shadow of the SARS-CoV-2 pandemic}

\author{
Ioana Munteanu ${ }^{1, *}$, Nicoleta Cioran ${ }^{2}$, Ramona Nedelcu ${ }^{3}$, Roxana Nemes ${ }^{4}$, Beatrice Mahler ${ }^{5}$
}

${ }^{1}$ Marius Nasta Institute of Pneumophysiology, NTP Manager, Bucharest, Romania

${ }^{2}$ NTP Epidemiology Surveillance Department, Carol Davila University of Medicine and Pharmacy, Bucharest, Romania

${ }^{3}$ NTP Epidemiology Surveillance Department, Marius Nasta Institute of Pneumophysiology, Bucharest, Romania

${ }^{4}$ Marius Nasta Institute of Pneumophysiology Bucharest, Titu Maiorscu University, Medicine Faculty, Bucharest, Romania

${ }^{5}$ Marius Nasta Institute of Pneumophysiology Bucharest, Carol Davila University of Medicine and Pharmacy, Bucharest, Romania

Abstract

\section{English:}

The provisory data collected by the tuberculosis (TB) Program in 2020 show that the global incidence decreases by $30 \%$, but considering the long interval from infection to the appearance of clinical manifestations in TB, we will be able to analyse only in the following years the positive or negative impact of the restrictive measures imposed as a result of the SARS-CoV-2 pandemic, on the evolution of TB in Romania.

Keywords

\section{Evolutia tuberculozei in Romania în umbra pandemiei cu SARS-COV2}

Rezumat

\begin{abstract}
Romanian:
Datele provizorii colectate la nivelul Programului National de Prevenie Supreaveghere si Control a Tuberculozei în Romania pentru anul 2020 se raportează o scădere a incidenței tuberculozei cu aproximativ $30 \%$, dar având în vedere intervalul mare de timp de la infecție la apariția manifestărilor clinice în TB vom putea analiza efectele pozitive sau negative impuse de Pandemia cu SARS-CoV-2 asupra tuberculozei în următorii ani.
\end{abstract}

Cuvinte-cheie

Tuberculoză • date epidemiologice • Pandemia cu SARS-COV2

Despite notable progress over the last decade, tuberculosis (TB) remains a public health problem, and a financial problem for health systems due to the high costs that the diagnosis, monitoring and treatment of resistant forms of TB can induce. The World Health Organisation (WHO) estimates made prior to the outbreak of the pandemic mention that in 2019, worldwide, 10 million people would became ill with TB, of which 5.6 million would be men, 3.2 million women and 1.2 million children; of these, 465,000 cases were anticipated to be resistant to rifampicin, of which $78 \%$ was predicted to be diagnosable with MDR-TB (1).

At the European level, through the sustained efforts of the European Center for Disease Control (ECDC) and the WHO, the estimated number of TB cases in the region has steadily decreased since 2000. In 2009-2018, the average annual decrease in incidence of TB was 5.1\%, with $6.0 \%$ between 2017 and 2018 , which was significantly higher than the overall rate of decrease in the incidence of TB $(2.0 \%)$, being the fastest rate decrease in the world. Translated into absolute values, the decrease by over 20,000 TB cases at the European level was ascertained. $^{2}$

This is in the context in which the burden of TB is not evenly distributed among the countries of the WHO European Region, and the MDR-TB rate is one of the highest in the world.

Romania is one of the 18 European countries affected by the burden of TB with notification rates of over 8 cases per 100,000 inhabitants and high incidence of multidrug resistance (MDR)/ extensively drug-resistant (XDR) TB. (The 18 countries

${ }^{*}$ Corresponding author: loana Munteanu

E-mail: loana.munteanu2015@yahoo.ro

ว Open Access. (C) 2021 Munteanu et al., published by Sciendo

(c) BY-NC-ND This work is licensed under the Creative Commons Attribution-NonCommercial-NoDerivs 4.0 License. 
mentioned above are the following, namely: Armenia, Azerbaijan, Belarus, Bulgaria, Estonia, Georgia, Kazakhstan, Kyrgyzstan, Latvia, Lithuania, the Republic of Moldavia, Romania, the Russian Federation, Tajikistan, Turkey, Turkmenistan, Ukraine and Uzbekistan).

However, in the last decade in Romania, there have been significant advances in TB control, which has led to a decrease in the incidence of TB and mortality by $5.3 \%-5.4 \%$ per year.

The TB incidence rate has decreased continuously since 2002 with a total per cent of 59.8 , resulting in an incidence of $57.4 \%$ in 2019 and with $73.9 \%$ in 2020 (3).

Ending in a notification of a number of 11,633 cases in 2019, these were distributed as follows: $3.4 \%$ are registered in children of $0-14$ years and $80.2 \%$ between individuals between the ages of 15 and 64 years. Most reported cases are registered in the age group of 45-49 years-1350, and the notification rate is at a maximum in the age group of 50-54 years (102.4 per 100,000 inhabitants). There was a tendency to increase the average age of notified TB patients in the period 2009-2018, from 43.0 years to 45.6 years. Usually, cases are registered in men and in rural areas (8263 and 6494 in 2019, respectively), the majority being pulmonary cases.
Unfortunately, the geographical distribution of cases on a country level has shown few variations in the last few years. The most affected counties remain those in the eastern and southern parts of the country, with dense population, poor zones and crowded villages. Incidence varies from $91.3 \%$ in Olt County to $16.2 \%$ in Harghita County.

In relation to risk factors and comorbidities from the total notified cases in 2018, it was observed that a quarter of patients were without occupation. With a number of 403 poor and 132 homeless, 2878 also had associative comorbidities. These data were extracted from the epidemiological software of the program. Some patients may have two or more comorbidities or be part of more than one category.

The TB incidence rate in children has also decreased continuously since 2002 with a total per cent of 73.40 , resulting in an incidence of $12.8 \%$ in 2019 (a maximum 45.3 in 100.000 children in lalomita County, a minimum of 2.0 in Harghita County and zero incident cases in Vrancea County). In 2020, TB incidence in children was $8.7 \%$.

The TB prevalence rate, which is a much tougher indicator to lower because it contains all categories of patients, has also decreased continuously since 2002 with a total per cent of 54.50 , resulting in a prevalence of $62.0 \%$ in 2020 .

\begin{tabular}{|c|c|c|c|c|c|c|c|c|c|}
\hline \multicolumn{10}{|c|}{ TB ESTIMATION IN THE WORLD, 2019} \\
\hline Region & $\begin{array}{l}\text { Population } \\
\text { (mil.) }\end{array}$ & $\begin{array}{c}\text { Best } \\
\text { estimated } \\
\text { number of } \\
\text { deaths } \\
\text { (thousands) }\end{array}$ & $\begin{array}{l}\text { HIV- } \\
\text { negative } \\
\text { TB } \\
\text { mortality- } \\
\text { best } \\
\text { estimate } \\
(\% 000)\end{array}$ & $\begin{array}{c}\text { Total TB } \\
\text { incidence- } \\
\text { best estimate } \\
\text { (thousands) }\end{array}$ & $\begin{array}{c}\text { Total TB } \\
\text { incidence- } \\
\text { best } \\
\text { estimate } \\
\text { (\%000) }\end{array}$ & $\begin{array}{l}\text { HIV-positive } \\
\text { TB incidence- } \\
\text { best estimate } \\
\text { (thousands) }\end{array}$ & $\begin{array}{c}\text { HIV } \\
\text { prevalence } \\
\text { in incident } \\
\text { TB- best } \\
\text { estimate (\%) }\end{array}$ & $\begin{array}{c}\text { Estimated } \\
\text { number of } \\
\text { incident } \\
\text { cases of } \\
\text { MDR/RR-TB } \\
\text { cases } \\
\text { (thousands) }\end{array}$ & $\begin{array}{l}\text { Incidence } \\
\text { rate } \\
\text { (estimate) } \\
\text { of MDR/RR- } \\
\text { TB (\%000) }\end{array}$ \\
\hline AFR & 1090 & 377 & 35 & 2470 & 226 & 595 & 24 & 77 & 7.0 \\
\hline AMR & 1010 & 17 & 1.7 & 290 & 29 & 29 & 10 & 11 & 1.0 \\
\hline EMR & 717 & 76 & 11 & 819 & 114 & 7.9 & 0.97 & 36 & 5.0 \\
\hline EUR & 930 & 20 & 2.2 & 246 & 26 & 30 & 12 & 70 & 7.5 \\
\hline SEAR & 2000 & 632 & 32 & 4340 & 217 & 117 & 2.7 & 171 & 8.6 \\
\hline WPR & 1930 & 85 & 4.4 & 1800 & 93 & 36 & 2.0 & 101 & 5.2 \\
\hline TOTAL & 7690 & 1210 & 16 & 9960 & 130 & 815 & 8.2 & 465 & 6.1 \\
\hline
\end{tabular}

Figure 1. TB estimation in the world, 2019. Source: Global TB Report 2020-Regional Profiles. National tuberculosis program epidemiological data base. AFR, Africa; AMR, Americas; EMR, Eastern Mediterranean; EUR, Europe; SEAR, South-East Asia; TB, tuberculosis. WPR, Western Pacific (1). 


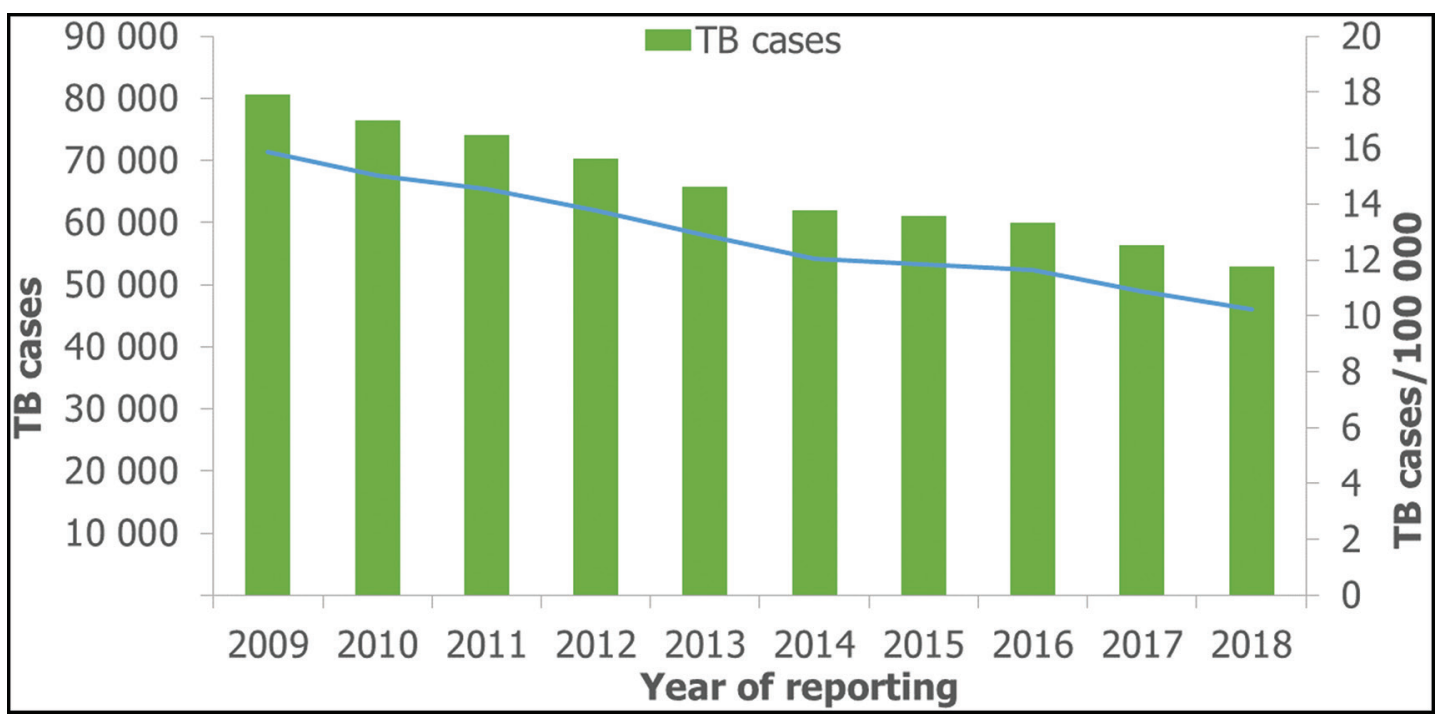

Figure 2. TB cases notified, EU/EEA, 2009-2018. Source: ECDC/WHO (2020). Tuberculosis surveillance and monitoring in Europe 2020-2018 data. TB, tuberculosis; WHO, World Health Organisation; EU, European Union; EEA, The European Economic Area; ECDC, European Centre for Disease Prevention and Control (2).

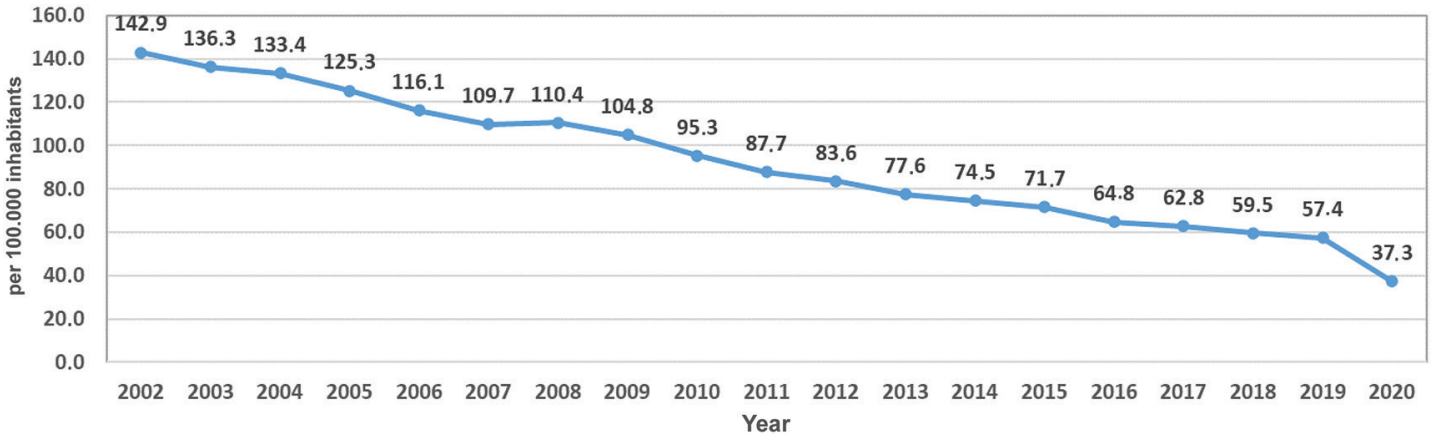

Figure 3. Global incidence in Romania between 2002 and 2020. (Epidemiological data register of the National TB Program).

The TB mortality rate has also decreased continuously since 2002 with a total per cent of 60.95 , resulting in a mortality of $4.1 \%$ in 2019 , which is similar to the target that was proposed through the TB National Strategy.

Human Immunodeficiency Virus (HIV) testing for TB cases has been on a continuous increase. In 2019, we tested over 10,047 cases from 11,633 notified cases, representing $86.4 \%$, and identified 200 HIV-positive cases, which number amounted to $2.5 \%$ of all the TB patients.

Increasing the laboratory diagnostic capacity is an important element in TB control, and it is also mentioned by the $\mathrm{WHO}$ / European Centre for Disease Prevention and Control (EDCD) action plan. The Ministry of Health and Romanian National TB Control Program have undertaken a lot of activities in this direction. A lot of laboratories were equipped with modern genotypic and phenotypic devices. This is reflected in an increasing number of sensibility tests and detection rate of Rifampicin (RIF) resistance and TB-drug resistance (DR) cases identification.

But the utilisation of GeneXpert as rapid method of diagnosis is still due to the increased price of the cartridge, which limits the utilisation according to the Program's limited budget.

The number of TB-MDR cases has also decreased since 2008 from a total of 792 cases to 304 cases in 2019, and this is a consequence of the treatment provided with the help of external funds.

The results of treatment of pulmonary confirmed cases $(C+$ and $\mathrm{M}+$ ) recorded in 2018 (except for MDR) and of MDRTB pulmonary cases recorded in 2017 are promising. The success rate is at $84.3 \%$ for new cases, $76.7 \%$ for relapses 


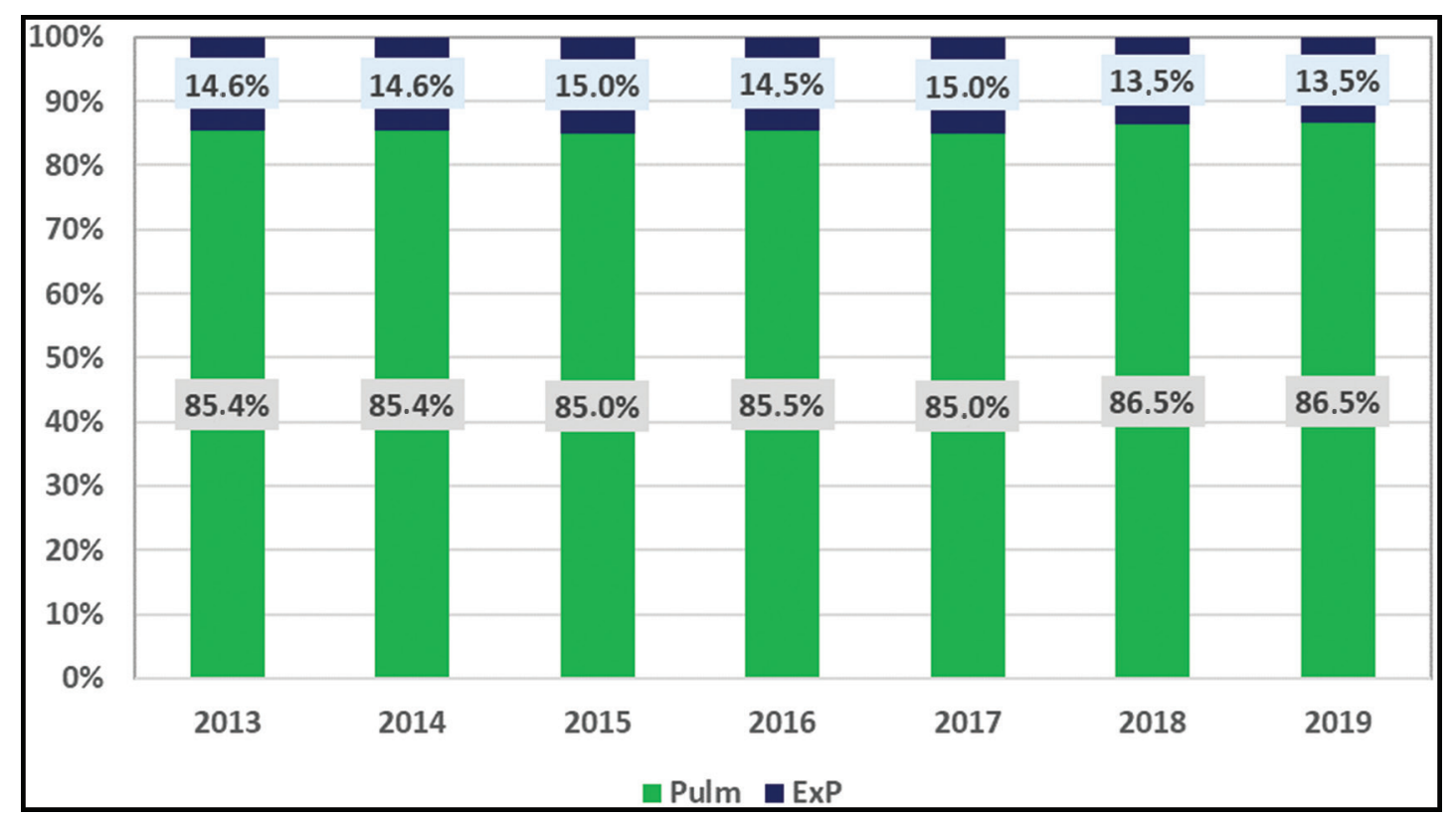

Figure 4. Notified case structure in Romania between 2013 and 2019, according to localisation of disease. Epidemiological data register of the National TB Program.

\begin{tabular}{|c|c|c|c|}
\hline \multicolumn{4}{|c|}{$\begin{array}{c}\text { Risk factors and comorbidities } 2018 \\
\text {-12205 TB patients- }\end{array}$} \\
\hline \multirow[b]{2}{*}{ Risk factors } & \multirow[b]{2}{*}{ No } & \multirow{2}{*}{\begin{tabular}{|l|} 
Comorbidities \\
Smoking \\
Alcoholism \\
\end{tabular}} & \multirow{2}{*}{\begin{tabular}{|l|} 
No (for 2878 patients) \\
817 \\
730
\end{tabular}} \\
\hline & & & \\
\hline Uninsured & 2772 & Liver disease & 580 \\
\hline Without & 4280 & Diabetes mellitus & 453 \\
\hline occupation & & TB contact & 380 \\
\hline Unemployed & 48 & Mental illness & 308 \\
\hline Poor & 403 & Cancer & 240 \\
\hline Homeless & 132 & Renal diseases & 112 \\
\hline Prisoners & 120 & Drug users & 70 (51 IDU) \\
\hline Migrant & 5 & Ulcer & 57 \\
\hline \multirow[t]{3}{*}{ Refugee } & 2 & Suppressive treatments & 46 \\
\hline & & Silicosis & 29 \\
\hline & & Pregnancy & 8 \\
\hline
\end{tabular}

Figure 5. Risk factors and comorbidities in notified patients in 2018. TB, tuberculosis. Epidemiological data register of the National TB Program. 


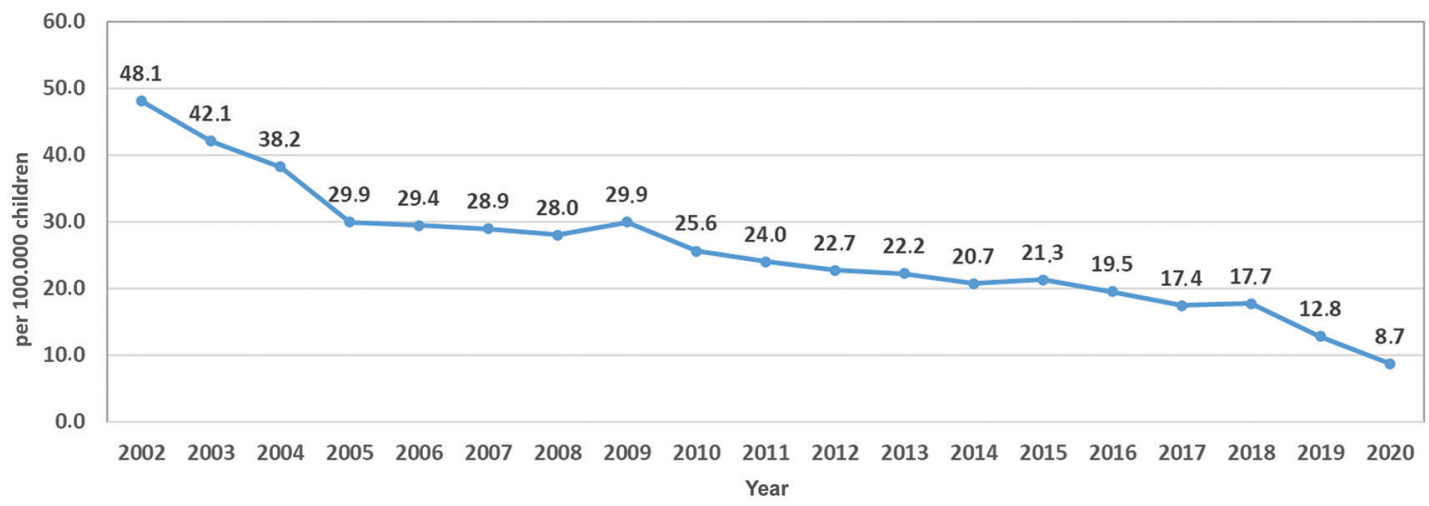

Figure 6. Global incidence in children in Romania between 2002 and 2020. Epidemiological data register of the National TB Program.

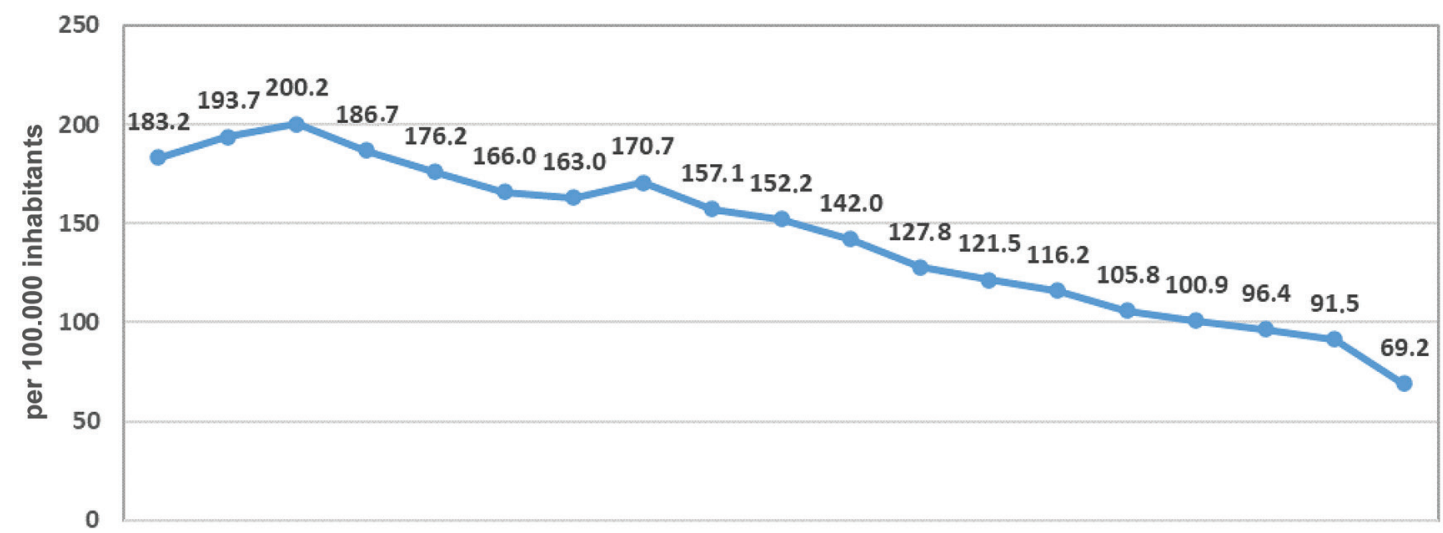

2002200320042005200620072008200920102011201220132014201520162017201820192020 Year

Figure 7. TB prevalence in Romania between 2002 and 2020. TB, tuberculosis. Epidemiological data register of the National TB Program.

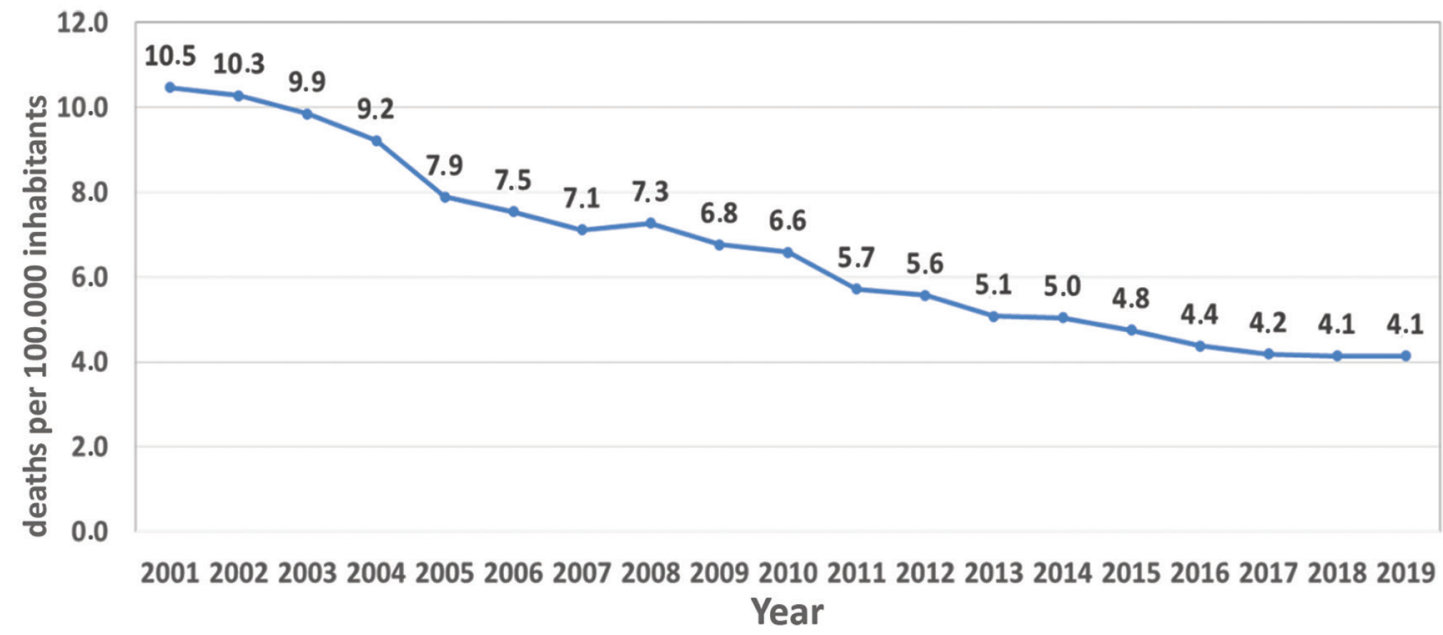

Figure 8. The mortality rate in Romania between 2001 and 2019. 


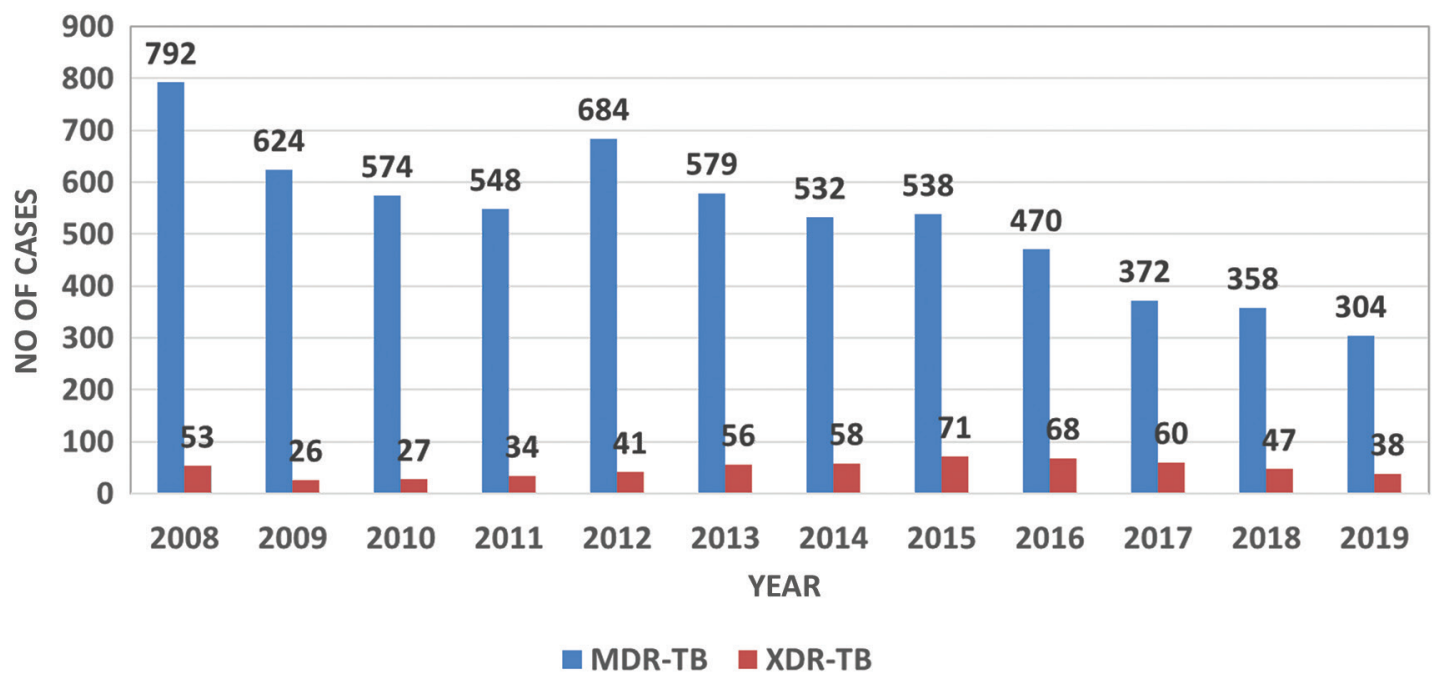

Figure 9. Number of TB-MDR/XDR cases in Romania between 2008 and 2019. TB, tuberculosis; MDR, multidrug resistance; XDR, extensively drug-resistant. Epidemiological data register of the National TB Program.

Table 1: Notified cases between 2017 and 2019 and number of cases with genetic tests. Epidemiological data register of the National TB Program.

\begin{tabular}{|l|c|c|c|}
\hline Period & $\begin{array}{c}\text { The number of } \\
\text { notified TB } \\
\text { cases }\end{array}$ & $\begin{array}{c}\text { The number of TB } \\
\text { cases with genetic } \\
\text { tests at the time of } \\
\text { diagnosis }\end{array}$ & $\begin{array}{c}\text { The percentage of } \\
\text { TB cases with } \\
\text { genetic tests at the } \\
\text { time of diagnosis }\end{array}$ \\
\hline Year $\mathbf{2 0 1 7}$ & 12.998 & 3.441 & $26.5 \%$ \\
\hline Year $\mathbf{2 0 1 8}$ & 12.199 & 2.902 & $23.8 \%$ \\
\hline Year $\mathbf{2 0 1 9}$ & 11.633 & 2.957 & $25.4 \%$ \\
\hline
\end{tabular}

TB, tuberculosis.

and $35.7 \%$ for MDR cases, which is a good progress; but still, it is under the proposed limit through the 2015-2020 National Strategy of $75 \%$. Therefore, the achievement of the Ministry of Health and National TB Program in the forthcoming years will be the assurance of complete and continuous therapeutic association of drugs, according to the National MDR Guide for the MDR/XDR patients, because drugs which target resolution of TB are expensive and it is necessary to find a proper way to cover the patients' needs. This is the only way to achieve MDR treatment target reach and a continuing decrease in the TB-DR incidence.

\section{Discussions}

According to these data, good progress has been made regarding the diagnosis and treatment of $T B$, which were possible with the help of external funds. Now we are facing a great challenge, namely sustainability by using national and governmental funds and the SARS-CoV-2 pandemic. ${ }^{4}$

The pathway of TB in the SARS-CoV-2 pandemic is a very difficult question. According to the $\mathrm{WHO}$, all the measurements of population moving limitation have induced slowness in patients accessing medical services. This may determine an increase with over 6.3 million cases of TB in the next 5 years and more than 14 million deaths, which represent a step back equivalent with $5-8$ years of TB control. ${ }^{5}$

In Romania, the SARS-CoV-2 pandemic has also resulted in a series of challenges for the pulmonologist involved in TB control, from the dispensary or hospital.

Starting from March, the number of cases of infection with SARS-CoV-2 has increased first slowly but later exponentially. In the third trimester, we achieved the psychological threshold of 10,000 cases per day. The government imposed 


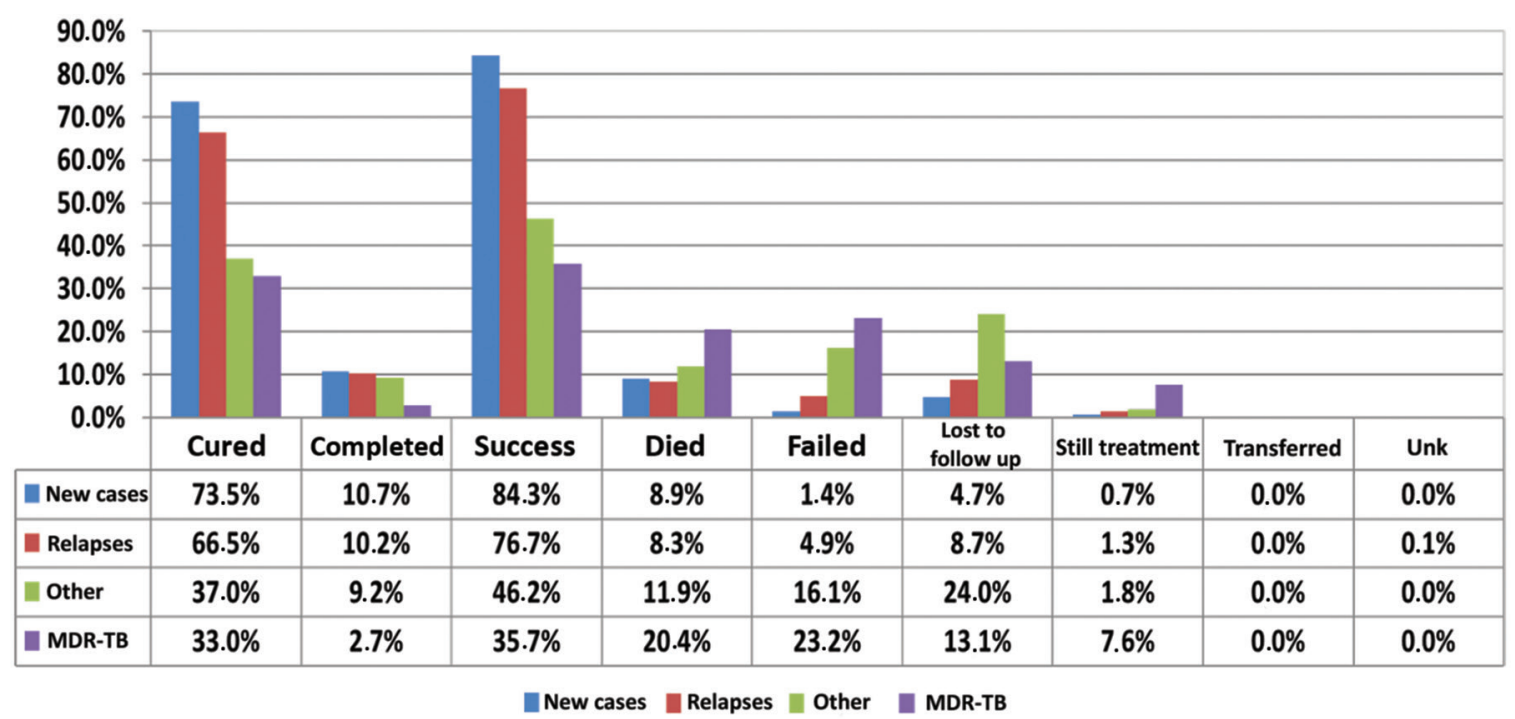

Figure 10. Treatment outcomes of pulmonary confirmed cases ( + + and $M+$ ), recorded in 2018 (except for MDR) and of MDR-TB pulmonary cases recorded in 2017. TB, tuberculosis; MDR, multidrug resistance, CN, New cases R, relapses. Epidemiological data register of the National TB Program.

an urgency statement that was followed by a state of alert, which involved a series of restrictive measures for pollution. ORDER nr. 555 from 3rd April 2020 was published in the Official Monitory, Part I, nr 290 from 7th April 2020. After the infections, disease hospitals and ambulatories, the pulmonology dispensaries and hospitals were the secondin-line affected.

The dispensary activities were cumulated or temporarily suspended from the usual location, the medical personnel were relocated in the COVID department and the Ministry of Health gave a lot of recommendations designed to limit the visits of TB patients in the dispensary, such as home distribution medicine, long periods for prescription, alternative methods for direct observation of treatment administration and monitoring the evolution under treatment. According to Order MS 500 from 23rd March 2020_regarding adjusting order $377 / 2017$ - it is notified that during the state of emergency, treatment can be prescribed, by case, for a period of 90/91/02 days for TB patients.

At hospital level, a large number of pulmonology departments were attributed to COVID patients' treatment, which resulted in a decrease in the number of beds for TB patients. So in hospitals, only patients with severe TB forms were admitted.

On the other hand, the patients did not access medical services because they had to respect authority recommendation, they assimilated the TB dispensaries and pulmonology departments with COVID departments and were afraid to contract the disease. The long period of waiting to respect the social distance rules was one other cause of postponed investigations that did not represent medical emergencies.

From the data collected to the NTP level, we can report some preliminary data.

TB-COVID situation (February-December 2020)

Thirty-one counties reported (including 6 Sectors M. Bucharest), of which 12 for the whole period.

The result was the declaration obtained from 2831 patients. Of these, $55.4 \%$ were not tested and $44.6 \%$ were tested. From the tested ones, $42.7 \%$ were COVID-19 negative and $1.9 \%$ were COVID-19 positive. These represent 52 patients with TB and COVID-19 positive. The patients can be classified as follows:

- Ages between 0 and 75 years, 46 masculine/6 feminine, 17 urban/35 rural;

- 40 new cases, 9 relapse, 3 other cases;

- 43 pulmonary.

- Evaluation:

$$
\begin{aligned}
& \text { - } \text { Cured }=3, \\
& \text { - Deaths as TB }=3 \\
& \text { - Deaths on account of other causes }=3 \\
& \text { - } \text { Failed }=2 \\
& \text { - } \text { Continue }=40 \\
& \text { - } \text { Defaulter }=1
\end{aligned}
$$

\section{Conclusions}

In this condition, from the provisory data collected by the TB Program in 2020, it is ascertained that the global incidence 
decreases by $30 \%$, but considering the long interval from infection to the appearance of clinical manifestations in $\mathrm{TB}$, we will be able to analyse only in the following years the positive or negative impact of the restrictive measures imposed by the SARS-CoV-2 pandemic on the evolution of TB in Romania.

\section{References}

1. GLOBAL TUBERCULOSIS REPORT $2020 \mathrm{http}$ ://chlaep.org. uy/wp-content/uploads/2020/11/Global-TB-report-2020.pdf.
2. Tuberculosis surveillance and monitoring in Europe 2020 -2018 data https://www.ecdc.europa.eu/en/publications-data/tuberculosis-surveillance-and-monitoring-europe-2020-2018-data.

3. Ghid Metodologic de Implementare a Programului National de Prevenire, Supraveghere si Control al Tuberculozei, Bucuresti 2015 aprobat prin, Ministerul Sănătății a emis Ordinul nr. $1171 / 21.09 .2015$.

4. Coronavirus disease (COVID-19) Weekly Epidemiological Update and Weekly Operational Update https://www.who.int/emergencies/diseases/novel-coronavirus-2019/situation-reports.

5. Tuberculosis and COVID-19 https://www.who.int/teams/globaltuberculosis-programme/covid-19. 